\title{
Failure Mechanism and Control Technology for a Large-Section Roadway under Weakly Cemented Formation Condition
}

\author{
Jiadi Yin, Baojie Fu (D, and Hualei Zhang (D) \\ Key Laboratory of Safe and Effective Coal Mining of the Ministry of Education, Anhui University of Science and Technology, \\ Huainan 232001, China \\ Correspondence should be addressed to Baojie Fu; 1506858187@qq.com
}

Received 27 October 2020; Revised 3 December 2020; Accepted 11 December 2020; Published 24 December 2020

Academic Editor: Zhigang Tao

Copyright (C) 2020 Jiadi Yin et al. This is an open access article distributed under the Creative Commons Attribution License, which permits unrestricted use, distribution, and reproduction in any medium, provided the original work is properly cited.

\begin{abstract}
The roof of a large-section roadway will usually undergo progressive deformation and failure under the action of deep surrounding rock stress. The large-section rectangular roadway is more prone to sudden roof caving accident under the weakly cemented formation condition, which poses great threats to operating personnel and mechanical equipment and brings about considerable difficulties to roof monitoring and evaluation. A large-scale caving accident that occurred on a large-section rectangular roadway in Bojianghaizi Mine in Inner Mongolia was taken as the study object. The factors that triggered the roadway roof caving were analyzed by investigating the roof caving mechanism of weakly cemented overlying strata, and an effective roof supporting method was proposed. A numerical mechanical analysis model was established for surrounding rocks of the roadway by using the discrete element method, and numerical simulation results showed that obvious vertical cracks would be generated at two ends of the roof under the action of shearing stress. With upward crack propagation and transverse crack penetration at the roof separation, a dangerous caving zone penetrated by cracks formed inside the roof. The permeation of the upper aquifer would reduce the rock strata strength at the roof and further aggravate the risk of roadway caving. In accordance with the numerical simulation and comprehensive analysis of field exploration data, the main reasons for the roadway caving accident were concluded as follows: (1) low rock strata strength at the roof and the influence of tectonic stress in deep surrounding rocks, (2) unreasonable original support pattern, and (3) permeation of the upper aquifer. On this basis, an improved support scheme was proposed, and field monitoring data showed that the maximum separation amount of the roof was controlled at $14 \mathrm{~mm}$, and the roof deformation was well controlled, thus meeting the safety production requirements. The proposed method can provide a reference for the control of weak roadway roof and its support scheme design.
\end{abstract}

\section{Introduction}

Coal is expected to remain a basic energy source that guarantees energy safety and stability in China for a long time. The proportion of coal in primary energy resource consumption is anticipated to exceed $50 \%$ by 2030 [1-3]. As coal mining is gradually transferred to the central and western regions in China, a large batch of mines have been successively constructed and put into production to exploit coal resources in weakly cemented formations in Central China in recent years. The physical and mechanical properties of rocks in central weakly cemented formations are mainly manifested by low strength, easy disintegration, argillization in water, and poor cementing properties. Groundwater permeation is usually encountered in the roadway tunneling process, and many experiments indicate that the moisture content of rocks has a great impact on the rock strength [4-8]. After absorbing water, the surrounding rocks of roadway will probably be exposed in water, which will aggravate the roof caving risk [9].

Many scholars have explored the roof caving problem in depth under different geological conditions. On the basis of a theoretical analysis, Tian et al. presented safety control criterion for a roof without support [10]. Kumar et al. developed a roof monitoring and early warning method [11]. Stanisław et al. proposed a roof caving evaluation method based on massive observation data [12]. According to test data and field observation data, Osouli et al. established a new 
numerical model, which could be used to estimate the maximum moisture content permitted by roof strata [13]. Ebrahim et al. studied the effective parameters that influence roadway roof caving and presented a semiquantitative technology for roof caving evaluation and control [14]. Crystal et al. came up with a microseismic monitoring method for roof caving and successfully predicted a roof caving accident twice [15]. Tai et al. analyzed the failure characteristics of a large-section coal roadway roof and developed a support scheme of grouting $+U$ steel bracket+anchor bolt+anchor rope [16]. Kang et al. used the numerical simulation method to investigate the internal mechanism of roadway deformation and instability and presented a new anchor bolt support scheme [17-19]. Wang et al. revealed the crack propagation and evolution process inside the surrounding rocks after roadway excavation through the UDEC numerical simulation method [20]. Bai et al. disclosed the internal roof caving mechanism through the numerical simulation method and presented a roadway deformation control scheme [21-25].

To sum up, many scholars have conducted much research regarding the prediction of roadway roof caving, the caving mechanism, and its control technology, but roadway caving disasters under weakly cemented formation conditions are less investigated. In weakly cemented formations, the surrounding rocks are of relatively low strength with great support difficulty. No evident sign of roof caving is found. Instead, the roof usually suddenly bursts out, which will not only result in injuries and deaths but also bring about adverse effects on the normal operation of coal mines. Under the engineering background of a caving accident in a largesection rectangular roadway caving accident that took place in Bojianghaizi Mine in Inner Mongolia, 3DEC numerical simulation was combined with field observation to reveal the internal roof caving mechanism, and a new support scheme is presented. The industrial experiment indicates that the new support scheme has achieved excellent effects in roof disaster prevention and control for large-section roadways.

\section{Engineering Background}

2.1. Geological Conditions. Bojianghaizi Mine is located in Inner Mongolia. As shown in Figure 1, the 113101 working face is located at $+803.5 \mathrm{~m}$ level of the mine, with an exploitable strike length of $2,600 \mathrm{~m}$, the roadway length in the south of the withdrawal channel is $2,677.3 \mathrm{~m}$, the inclined length is $200 \mathrm{~m}$, and the inclined longwall-type coal mining method is used. The $3-1 \#$ coal seam has a nearly horizontal monoclinal structure, with a strike angle of $30^{\circ} \sim 60^{\circ}$, an angle of deviation of $300^{\circ} \sim 330^{\circ}$, and pseudoobliquity of $0 \sim 1.5^{\circ}$.

The gate road of the 113101 working face is arranged in the 3-1\# coal seam, which has a thickness of $3.4 \sim 3.8 \mathrm{~m}$ near the roof caving segment, containing 3-4 thin layers of mudstone with coal gangues. The immediate roof of the 3-1\# coal seam in this segment is sandy mudstone, with a thickness of $6.5 \sim 9.3 \mathrm{~m}$. According to the mechanical test on rock core in drill hole in the reconnaissance report, the compressive strengths of the rocks are low, the average compressive strength is below $30 \mathrm{MPa}$, the shear strength and tensile strength are even lower, the compressive strength is obviously reduced under water absorption state of the rocks, and the softening coefficients are all smaller than 0.75 , thus indicating that they are all soft rocks. The lithology and thickness of each rock stratum are shown in Figure 2.

2.2. Initial Roadway Support Form. As one of the important transportation roadways of Bozi Mine, the 113101 main transportation roadway is $5.6 \mathrm{~m}$ in width and $3.6 \mathrm{~m}$ in height. It is supported by combining anchor bolt+anchor rope, and the complete support is shown in Figure 3(a). The anchor bolts used on the roof and two walls are made of $\varphi 22 \times 2500 \mathrm{~mm}$ resin high-strength screw-thread steel anchor bolts. Two rolls of $\mathrm{k} 2360$ resin anchoring agent are used for each anchor bolt. The specifications of $\mathrm{W}$ steel strips are $\delta 3 \times 178 \times 5400 \mathrm{~mm}$; their spacing is shown in Figure 3(b), and the row spacing is $900 \mathrm{~mm}$. The specifications of the anchor ropes are $\varphi 17.8 \times 6300 \mathrm{~mm}$, with a spacing of $1400 \mathrm{~mm}$ and a row spacing of $1800 \mathrm{~mm}$. Three rolls of k2360 resin anchoring agent are used for each anchor rope, and the specifications of $\mathrm{W}$ steel stripe are $\delta 3 \times 250 \times 3200 \mathrm{~mm}$.

2.3. Roof Instability Caving Accident. Groundwater permeation is a common phenomenon in the roadway excavation process. The strength of weakly cemented rocks will evidently degrade in water, and the roadway will easily experience instability failure. The position in Bojianghaizi Mine in Inner Mongolia, where the roadway roof caving accident occurred, is shown in Figure 1(b). The caving part is $683 \mathrm{~m}$ away from the transportation roadway, the roof caving segment is $14.6 \mathrm{~m}$ in length, and the scene photo is shown in Figure 4.

As shown in Figure 4(a), a hole was drilled in the roadway roof to discharge water. The sand content was high in the discharged water, the water release was gradually reduced before the accident occurred, hole collapse and blocking were possible, and the water flow permeated laterally. The sandy mudstone on the roof experienced argillization after water erosion, which led to the reduction in the strength of the surrounding rock and to support failure. In the field repair process, the roadway was supported by channel steel-combined anchor bolts+U-shaped steel arched sheds. Figure 4(b) shows the roof caving form observed on the field. The whole roof caved from the rock strata section. The site survey on the caving zone showed that an obvious fractured joint surface under upward propagation existed on the rock strata at the vertex angle, and this surface presented a $65^{\circ}$ angle along the horizontal direction (Figure 4(c)). When encountering water, the strength of the surrounding rocks would be reduced. Moreover, the bonding strength of anchor bolts and anchor ropes with surrounding rocks would be reduced, thus causing separation. As shown in Figure 4(d), the anchoring agent on the surface of the anchor bolts and ropes already basically fell off, but the anchor bolts and ropes themselves were not damaged. 


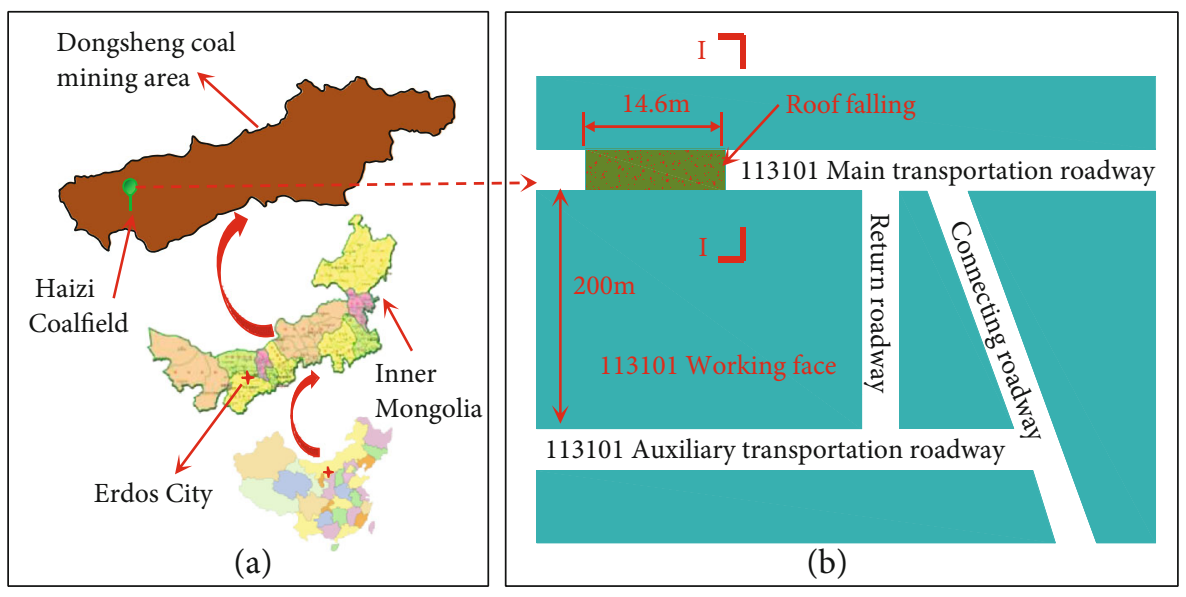

Figure 1: Coal mine position and roadway arrangement plan ((a) position of Haizi Mine area; (b) arrangement plan of roadway where the caving accident occurred).

\begin{tabular}{|c|c|c|c|}
\hline \multirow{2}{*}{ I-I cross-section } & Number & Lithology & Thickness, $\mathrm{m}$ \\
\hline & 1 & Fine sandstone & $20 \mathrm{~m}$ \\
\hline Roof Roof failure & 2 & Sandy mudstone & $9 \mathrm{~m}$ \\
\hline Coal & 3 & 3-1 Coal & $4.4 \mathrm{~m}$ \\
\hline \multirow[t]{3}{*}{ Transportation roadway } & 4 & Sandy mudstone & $2 \mathrm{~m}$ \\
\hline & 5 & Medium sandstone & $7 \mathrm{~m}$ \\
\hline & 6 & Fine sandstone & $20 \mathrm{~m}$ \\
\hline
\end{tabular}

FIgURE 2: Rock strata histogram at the 113101 main roadway.

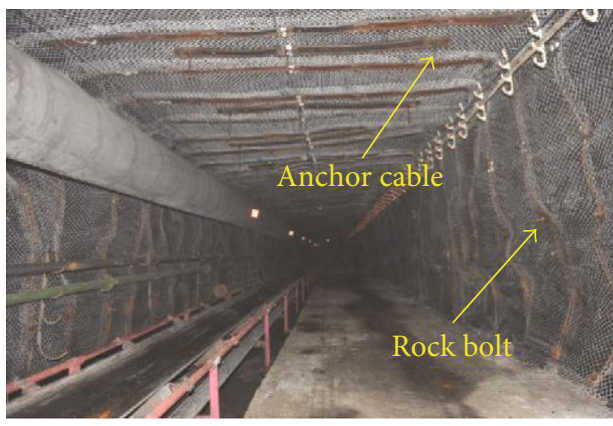

(a)

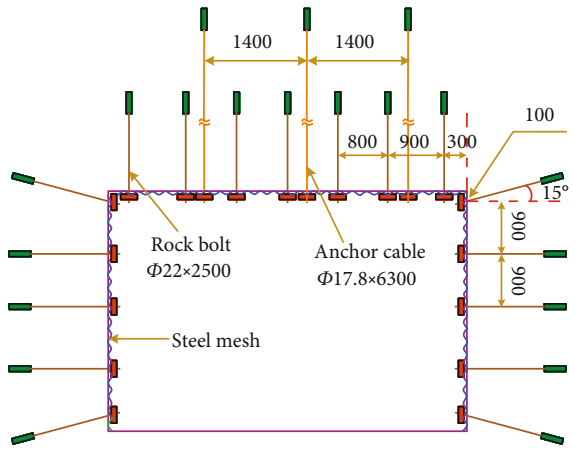

(b)

Figure 3: Initial roadway support scheme. (a) Field support picture. (b) Support spacing arrangement.

\section{Numerical Simulation Analysis via Discrete Element Method}

3.1. Model Establishment. To intuitively reflect the failure process of the roadway roof, a 3DEC numerical analysis model was established according to related geological conditions of Bozi Mine (Figure 5). The length, height, and width of the model were 70,63 , and $20 \mathrm{~m}$, respectively. To investigate the deformation and instability process of the roof, the $3 \mathrm{D}$ triangle method was used to express the immediate roof as a combination of tetrahedral blocks bonded together through their contact surfaces. The size of the tetrahedral blocks was $0.2 \mathrm{~m}$ (Figure 5(c)). Each tetrahedral block was elastic and deformable; therefore, they would not yield. Yield would occur along the contact surface between the tetrahedral blocks only through shear force or tensile force, which depended on the contact force and physical characteristics of the contact surface $[26,27]$, the latter of which is listed in Table 1. Before the failure, the contact points were elastic in both the normal direction and the shear direction. Within each time step, the increment of normal force (positive under pressure) is [28]

$$
\Delta F^{\mathrm{n}}=-k_{\mathrm{n}} \Delta u_{\mathrm{n}} A_{\mathrm{c}} .
$$




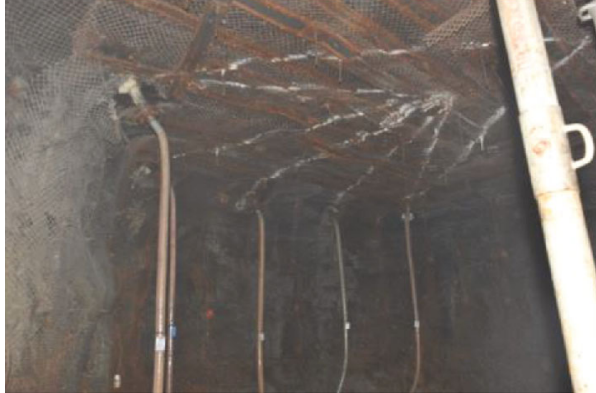

(a)

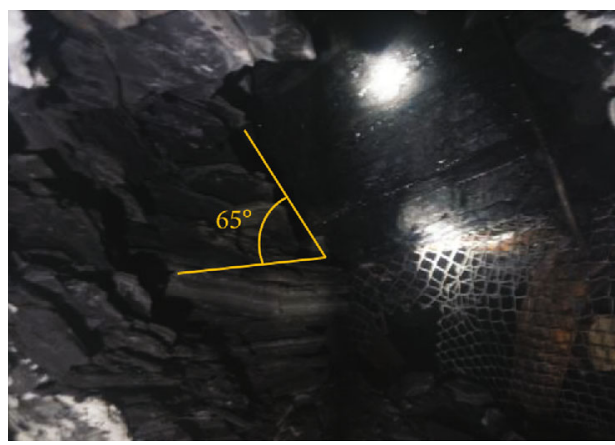

(c)

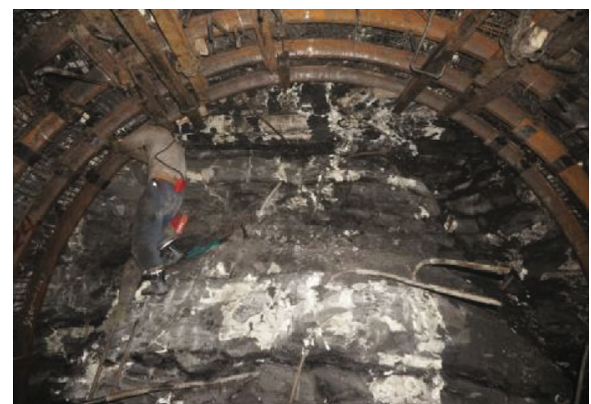

(b)

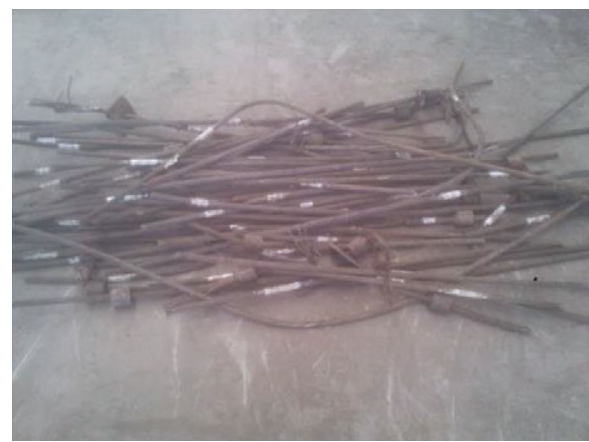

(d)

FIgURE 4: Roof caving accident in Haizi Mine. (a) Water release through drill hole at the roof. (b) Roof caving. (c) Fractured joint surface. (d) Separated anchor bolts and anchor ropes.

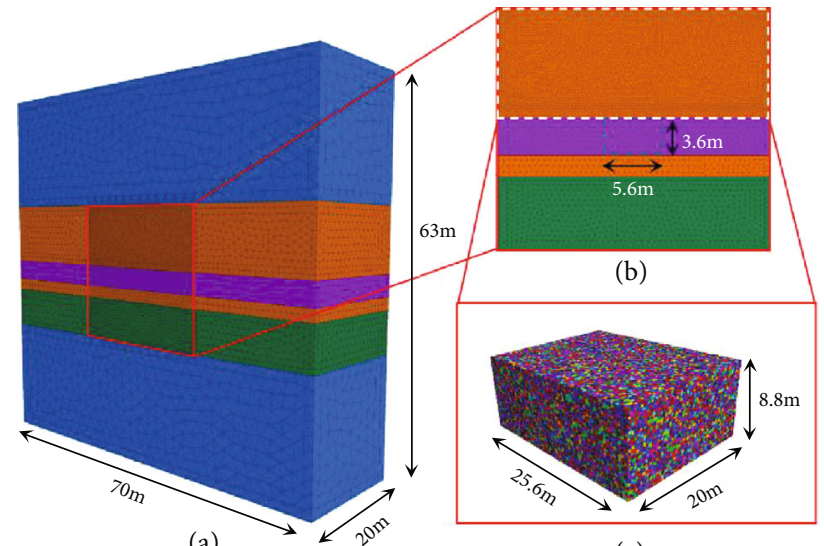

(a)

(c)

FiguRE 5: 3DEC numerical analysis model. (a) Complete model. (b) Grid refinement region. (c) Roadway roof.

TABle 1: Properties assumed in 3DEC model for immediate roadway roof.

\begin{tabular}{|c|c|}
\hline Contact properties & Values \\
\hline Young's modulus of blocks, $E(\mathrm{GPa})$ & 5.0 \\
\hline Poisson's ratio of blocks, $v$ & 0.23 \\
\hline Normal stiffness of contacts, $k_{\mathrm{n}}(\mathrm{GPa} / \mathrm{m})$ & 12 \\
\hline Shear stiffness of contacts, $k_{\mathrm{s}}(\mathrm{GPa} / \mathrm{m})$ & 4.5 \\
\hline Contact cohesion, $c^{\text {cont }}(\mathrm{MPa})$ & 4.2 \\
\hline Contact friction angle, $\varphi^{\text {cont }}\left({ }^{\circ}\right)$ & 20 \\
\hline Contact tensile strength, $\sigma_{\mathrm{t}}{ }^{\text {cont }}(\mathrm{MPa})$ & 3 \\
\hline
\end{tabular}

The shear stress increment is as follows:

$$
\Delta F_{\mathrm{i}}^{\mathrm{s}}=-k_{\mathrm{s}} \Delta u_{\mathrm{i}}^{\mathrm{s}} A_{\mathrm{c}},
$$

where $A_{\mathrm{c}}$ is the contact area, and $k_{\mathrm{n}}$ and $k_{\mathrm{s}}$ are the normal stiffness and the shear stiffness of contact, respectively.

The total normal force and shear force are updated in the following contact forces:

$$
\begin{aligned}
F^{\mathrm{n}} & :=F^{\mathrm{n}}+\Delta F^{\mathrm{n}}, \\
F_{\mathrm{i}}^{\mathrm{s}} & :=F_{\mathrm{i}}^{\mathrm{s}}+\Delta F_{\mathrm{i}}^{\mathrm{s}} .
\end{aligned}
$$

For an intact block (namely, without slipping or separation), the normal tensile force is limited as

$$
\begin{gathered}
T_{\max }=-T A_{c}, \\
F_{\max }^{\mathrm{s}}=c A_{\mathrm{c}}+F^{\mathrm{n}} \tan \phi,
\end{gathered}
$$

where $T$ is the tensile strength of the contact, and $c$ and $\phi$ are the cohesion and frictional angle of the contact, respectively.

Except for the roadway roof, other parts of the model were expressed by parallel hexahedral blocks under elastic deformation. To improve the calculation efficiency, the side length of the grids in the grid reinforcement region around the roadway was set as $0.5 \mathrm{~m}$, that in the central region as $1 \mathrm{~m}$, and that of the fine sandstone bed at the bottom of the roof as $2 \mathrm{~m}$ (as shown in Figure 5).

3.2. Numerical Calibration. The values of the rock properties at the roadway roof could not be directly assigned in the 


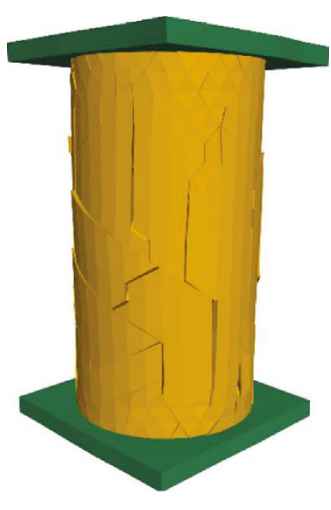

(a)

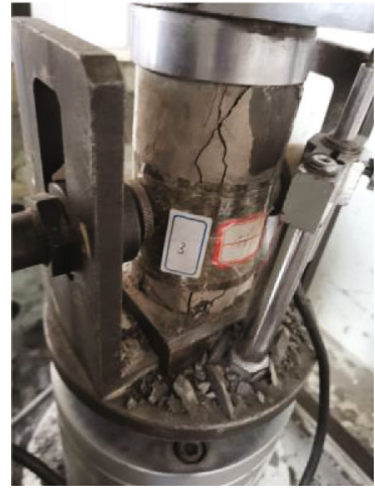

(b)

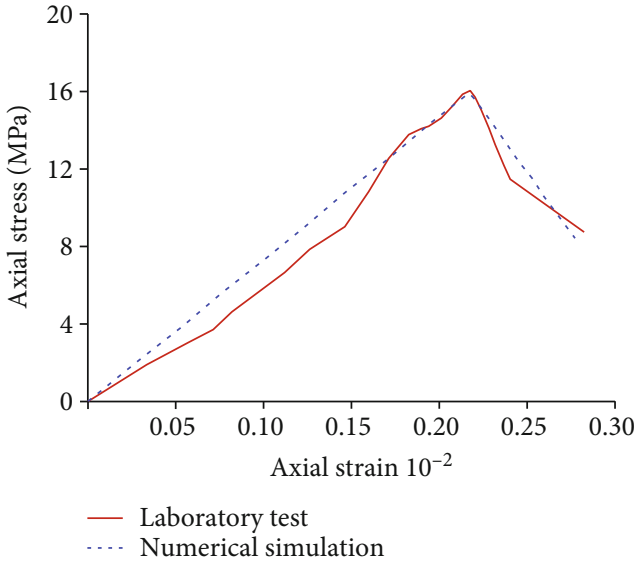

(c)

FIGURE 6: Check of uniaxial test. (a) Numerical model of uniaxial compression. (b) Uniaxial test in laboratory. (c) Uniaxial test curves of rocks.

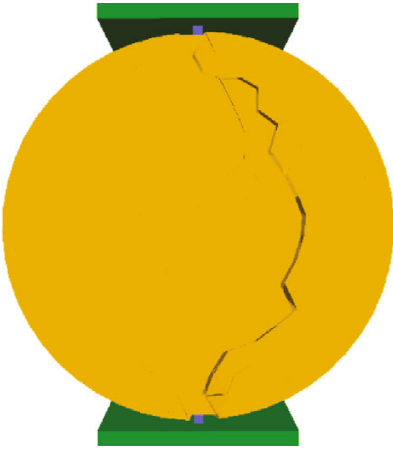

(a)

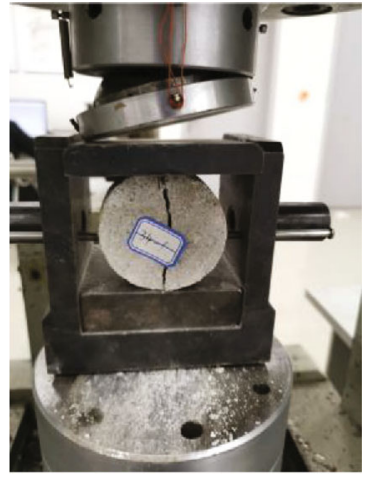

(b)

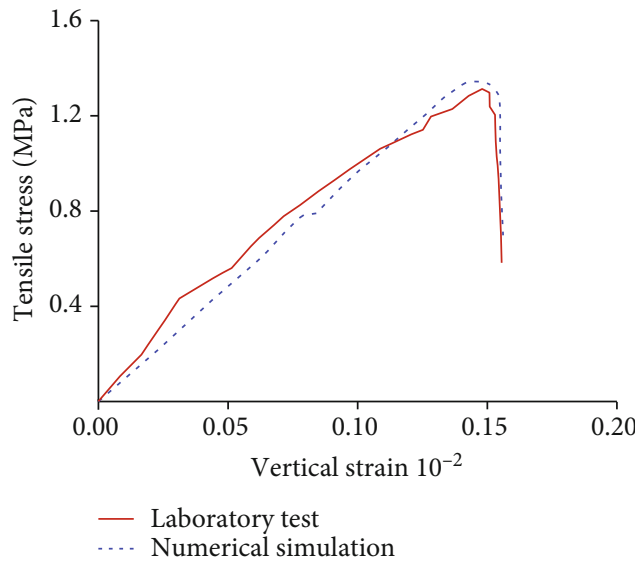

(c)

FIGURE 7: Check of Brazilian splitting test. (a) Numerical model of splitting test. (b) Splitting test in laboratory. (c) Tensile test curves of rocks.

model. Therefore, numerical calibration was needed to acquire the mechanical parameters of the contact point and polygon, which were used to characterize the rock behaviors [21]. The Young's modulus, Poisson's ratio, and uniaxial compressive strength were determined through a uniaxial compression test, and the tensile strength was measured by the Brazilian test. The geometric shape of the 3DEC uniaxial compression test model is presented in Figure 6. The uniaxial compression test sample was composed of 12,282 tetrahedral blocks (width: $0.2 \mathrm{~m}$ ), with a height of $4 \mathrm{~m}$ and a diameter of $2 \mathrm{~m}$, and two rigid bearing plates were placed at the top and bottom. The Brazilian disk test sample was $4 \mathrm{~m}$ in diameter and $0.5 \mathrm{~m}$ in thickness, and its numerical model consisted of 5,876 tetrahedral blocks (width: $0.2 \mathrm{~m}$ ).

The mechanical properties and contact parameters of the tetrahedral blocks in the 3DEC block model are seen in Table 1. The details of parameter calibration can be found in the work of Kazerani and Zhao [29]. In the compression test, the top plate of the sample was loaded at a constant rate of $0.1 \mathrm{~m} / \mathrm{s}$. The whole lower plate was fixed at a low enough loading rate; therefore, the influence of loading rate on the numerical test could be neglected [30]. The stress and axial deformation of the sample were monitored in the loading process (as shown in Figures 6(c) and 7(c)).

3.3. Crack Evolution Process at the Roof. A numerical analysis of the surrounding rocks of the roadway under initial support conditions was conducted to analyze the internal roof caving mechanism under this circumstance. The physical parameters of the rock strata are listed in Table 2. The numerical simulation results are shown in Figure 8(c). The maximum displacement of the roadway was $279 \mathrm{~mm}$. Many cracks appeared at $0.9 \mathrm{~m}$ from the roadway roof, and the surrounding rocks underwent evident crushing. At $2.8 \mathrm{~m}$ away from the roof, crushing occurred within a small range and many cracks appeared, and the cracks propagated and developed to form a through fractured zone. The surrounding rocks were basically intact at $6.5 \mathrm{~m}$ from the roof, along with a small quantity of cracks. YSZ (B) rock strata detection recorder was used 
TABle 2: Physico-mechanical parameters of ore-rocks.

\begin{tabular}{|c|c|c|c|c|c|c|}
\hline Lithology & $\begin{array}{l}\text { Density } \\
\left(\mathrm{kg} / \mathrm{m}^{3}\right)\end{array}$ & $\begin{array}{l}\text { Bulk modulus } \\
(\mathrm{GPa})\end{array}$ & $\begin{array}{l}\text { Shear modulus } \\
(\mathrm{GPa})\end{array}$ & $\begin{array}{l}\text { Tensile strength } \\
(\mathrm{MPa})\end{array}$ & $\begin{array}{l}\text { Cohesion } \\
(\mathrm{MPa})\end{array}$ & $\begin{array}{c}\text { Internal friction angle } \\
\left({ }^{\circ}\right)\end{array}$ \\
\hline Fine sandstone & 2650 & 6.2 & 4.8 & 2.2 & 3.2 & 43 \\
\hline Sandy mudstone & 2600 & 2.52 & 1.5 & 1.3 & 1.9 & 40 \\
\hline 3-1 coal & 1600 & 1.6 & 1.13 & 0.9 & 1.3 & 32 \\
\hline $\begin{array}{l}\text { Medium } \\
\text { sandstone }\end{array}$ & 2620 & 3.52 & 2.65 & 1.8 & 2.8 & 38 \\
\hline
\end{tabular}

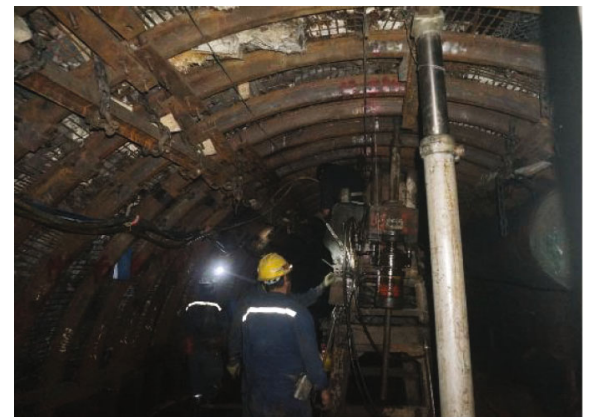

(a)

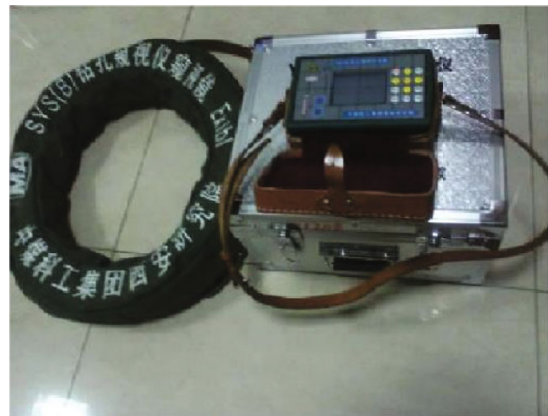

(b)

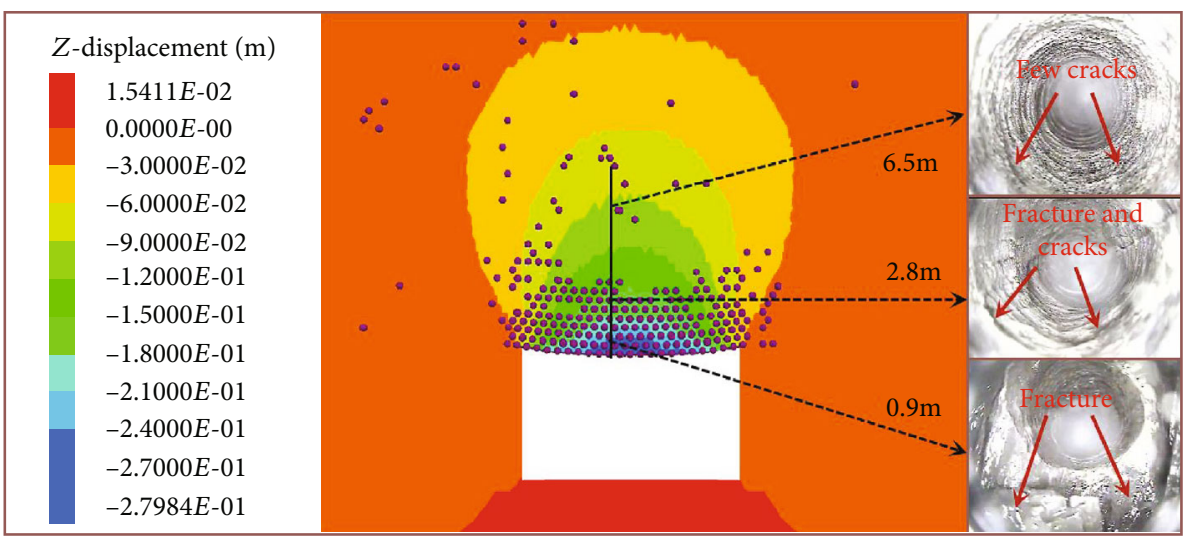

(c)

Figure 8: Crack development in roadway roof. (a) Drill hole at roadway roof. (b) Rock strata detection recorder. (c) Roadway roof deformation.

to drill a hole and peer at the roadway roof nearby the accident site (as shown in Figures 8(a) and 8(b)). The numerical simulation results of the cracks were basically consistent with the field drilling results, thus verifying the reasonability of the numerical simulation.

To study the crack evolution process inside the roof strata, the internal crack development process was recorded (as shown in Figure 9). The cracks appeared at the bottom and two ends of the roof first, and separation took place between top coal and sandy mudstone. As the operation step number increased, the displacement of the separation bed was gradually enlarged and transferred from the shallow part to the deep part step by step. The vertical cracks presented an upward development trend and finally ran through the transverse cracks in the separation bed, thus reducing the roof bearing capacity and further causing the risk of caving.
3.4. Cause Analysis for Roof Caving. The roof strata of the roadway were mainly sandy mudstone, which would undergo a rapid reduction in strength, cohesion, and tensile strength. Moreover, the roadway was prone to instability failure. A numerical simulation analysis of the deformation characteristics after roof strata softening was conducted (Figure 10). After the roof strata were weakened, an obvious increasing number of cracks were developed, the separation phenomenon occurred in the deep part of the rock strata, and the maximum settlement amount of the roof reached $380 \mathrm{~mm}$. The crack development was apparent at the vertex angle of the roadway, and the development height in the through fractured zone was increased. The bearing capacity of the roof strata was degraded, and the overall caving risk was observed below the roof.

Distributions in the surrounding rocks of the roadway after the numerical model operated for different steps are displayed in Figure 11. After the roadway was excavated, the 


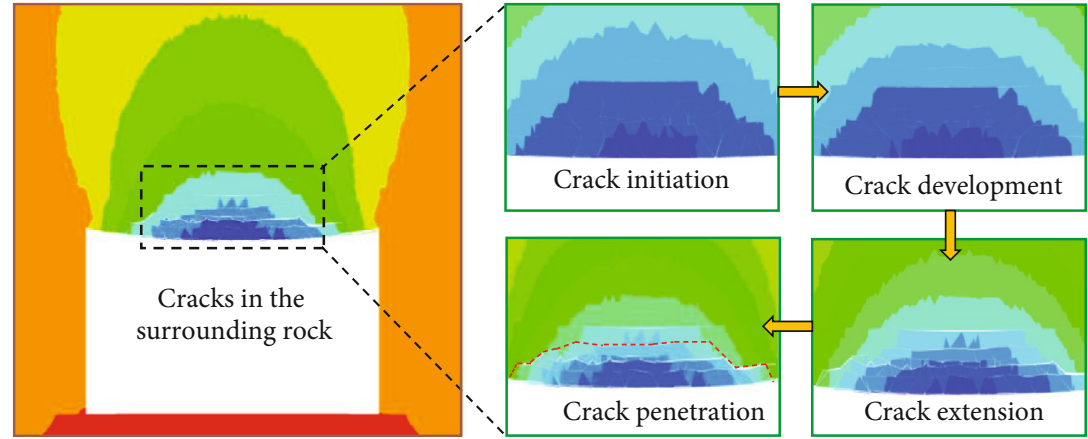

Figure 9: Crack evolution process in the roof.

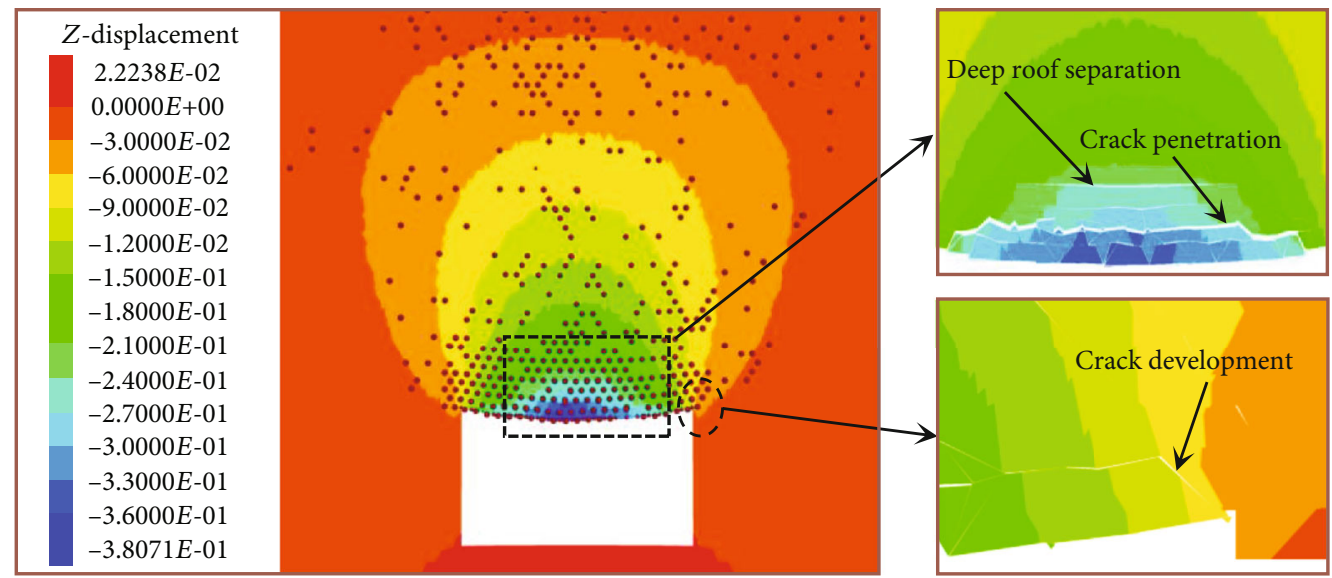

Figure 10: Crack development after roof weakening.

deep surrounding rock stress was released, and concentrated stress formed at the vertex angle at both ends of the roadway roof. As shown in Figure 11(b), the concentrated stress reached $26 \mathrm{MPa}$ at the vertex angle of the roadway. As the number of operation steps increased, the scope of stress release was gradually extended upward. Many obvious cracks would be generated in the rock strata under the action of the concentrated stress around the vertex angle, which was adverse to the roof stability (Figures 10 and $11(\mathrm{~d})$ ).

On the basis of the numerical simulation and field observation results, the three following aspects are concluded as the causes of the roof caving.

The strength of the roof strata was poor. Along with the primary deposits and diagenesis, the degree of consolidation of the bedding plates was low at the rock strata, with poor rock cementing properties and weak interlayer adhesion, and separation phenomenon could easily take place during the roof settling process. The compressive strength and tensile strength of the roof strata were weak, which was why cracks obviously developed in the rock strata during the stress release process in the surrounding rocks, and a through fractured zone easily formed beneath the roof.

The roadway span was large, and the sectional form and support design were unreasonable. Anchor bolt+anchor rope combined support was adopted in the initial support design, where the length of the anchor rope was $6.3 \mathrm{~m}$. The strike root of the anchor rope was located in the sandy mudstone with poor lithology, which is why the anchoring effect was unsatisfactory. The stress concentration could easily form at the roadway shoulder corner, with a large quantity of vertical cracks, which presented an evident upward development trend.

Groundwater generated a weakening effect on the surrounding rocks of the roadway. The casing pipe was sealed only to the $10 \mathrm{~m}$ position during the water release process via a drill hole. Thus, groundwater would laterally permeate into the roof, and the sandy mudstone experienced expansion and argillization, thereby reducing the strength and aggravating the caving risk.

\section{Roof Control Technology}

4.1. New Support Scheme. An improved roadway support scheme was presented based on the cause analysis for roadway caving. (1) The shoulder corner of the rectangular roadway changed into a rounded angle with a radius of $1 \mathrm{~m}$, which could reduce the concentrated stress at the shoulder corner of the rectangular roadway, facilitate the formation of bearing arch, and improve the bearing capacity and stability of the roof strata. (2) The length of the 


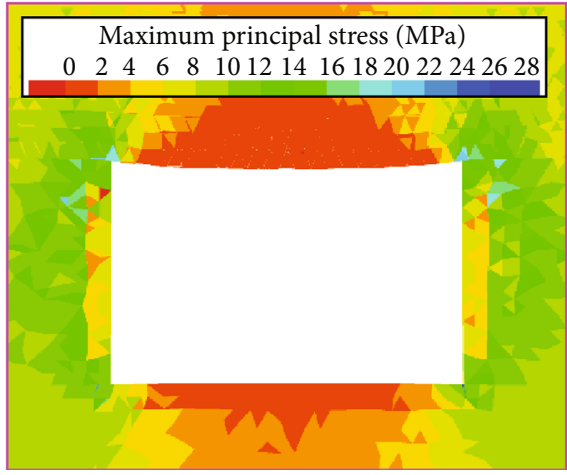

(a)

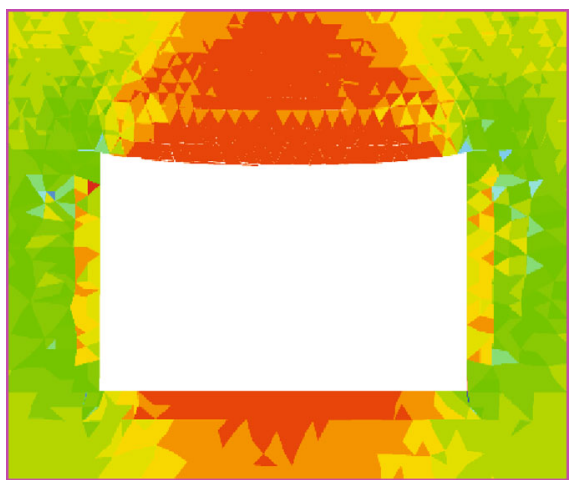

(c)

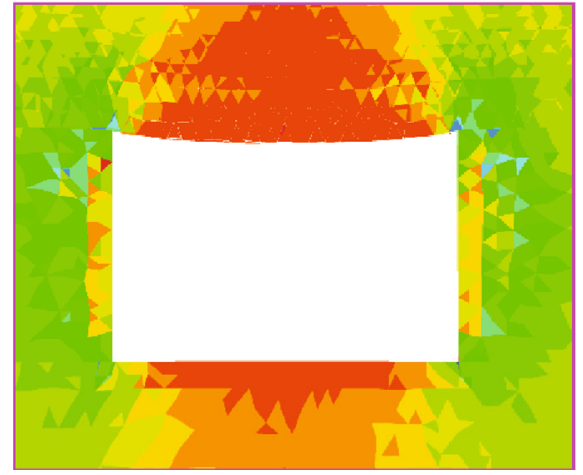

(b)

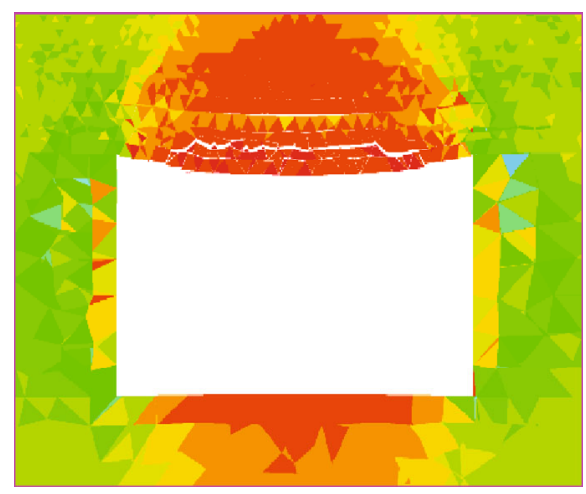

(d)

FIGURE 11: Maximum principal stress distribution in surrounding rocks of the roadway after model operation for different steps. (a) 500 steps. (b) 1,000 steps. (c) 2,500 steps. (d) 10,000 steps.

anchor rope was increased, and the root part of the anchor rope was arranged inside the upper roof with favorable lithology. The anchor ropes were arranged in an external cable-stayed pattern, and the inclined extrusion force at two sides of the roof was enlarged, thus effectively inhibiting the upward propagation of inclined cracks. The double cable-stayed anchor ropes could form a wedge-shaped bearing structure inside the roof, which could strengthen the support and prevent the overall caving of the reinforced roof zone. (3) The length of the existing water release casing pipe was properly increased according to the lithological change of the roadway roof to prevent the blocking of the drain hole and avoid the weakening effect of lateral permeation on the rock strength at the roof.

The concrete support scheme is presented in Figure 12. The section of the transportation gate road was largely rectangular, where the two vertex angles were connected to the vertical wall and roof using $1 / 4$ arc with a diameter of $2.0 \mathrm{~m}$. $\varphi 22 \times 2500 \mathrm{~mm}$ anchor bolts were used to support the roof; the matching steel strip was W3 steel stripe, where $L=5.4 \mathrm{~m}$; the metal net was $8 \#$ rhomboid galvanized metal net, with specifications of $6000 \times 1100 \mathrm{~mm}$; the row spacing of anchor bolts was $800 \times 900 \mathrm{~mm}$, and the specifications of the anchor ropes were $\varphi 17.8 \times 10000 \mathrm{~mm}$ with a row spacing of $1400 \times 1800 \mathrm{~mm}$. The matching steel strip was 3 S steel stripe, where $L=3.2 \mathrm{~m}$, the anchor ropes were externally

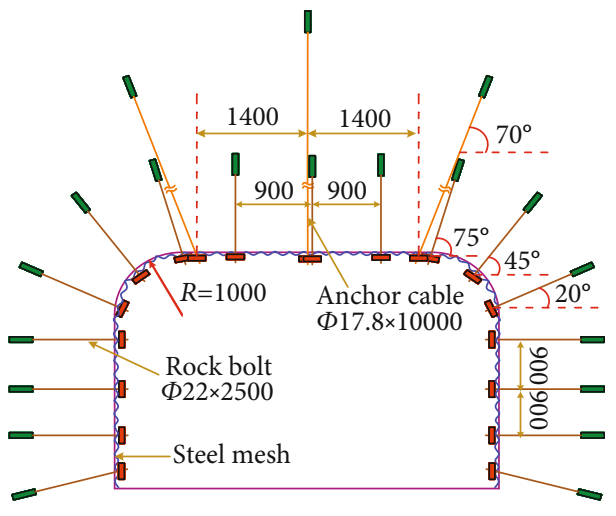

Figure 12: Improved roadway support scheme.

inclined near the two walls and presented $70^{\circ} \sim 75^{\circ}$ angles with the roof.

4.2. Numerical Simulation Results. The numerical simulation results of the new support scheme are displayed in Figure 13. The displacement of the roadway roof was $202 \mathrm{~mm}$, which was reduced by $27.6 \%$ compared with that in the initial support scheme. The crack development height was obviously reduced, and the crack density was high only beneath the roof. A few through cracks were found inside the roof, which were mainly concentrated below the roof. As shown in Figure 13, the roof separation 


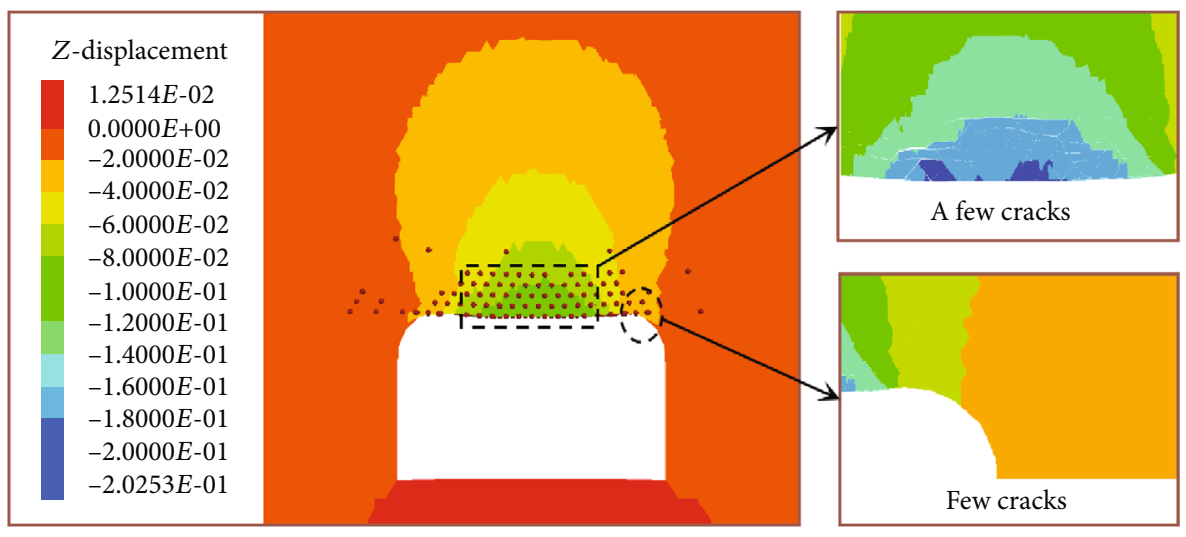

FIGURE 13: Crack development in roadway roof after the improvement of the support scheme.

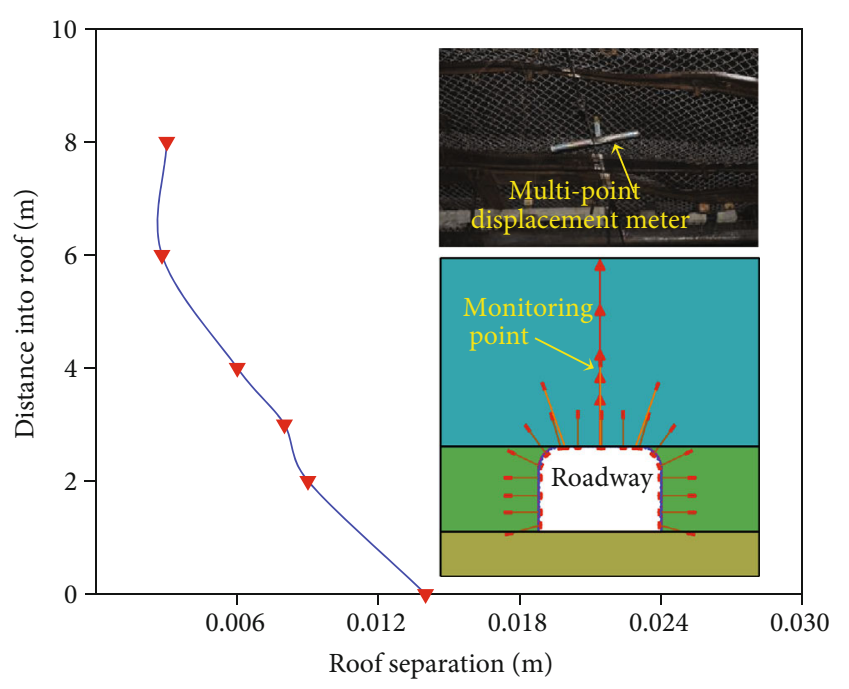

FIGURE 14: Separation monitoring of roadway roof.

mainly occurred within a $1.2 \mathrm{~m}$ range from the undersurface of the roof, and no obvious separation phenomenon appeared deep in the rock strata. No obvious cracks developed at the rounded corner of the roadway roof, and the integrality of the surrounding rocks was obviously improved. In comparison with the initial support scheme, the roof stability was well improved.

\section{Engineering Application}

An improved support scheme was presented for the caving accident in the 113101 main transportation roadway of Bojianghaizi Mine. The new support scheme was selected in the subsequent excavation process of this roadway, and the supporting effect was evaluated through field observation. To monitor the deformation of the roadway roof, displacement meters were placed at 2, 3, 4, 6, and $8 \mathrm{~m}$ inside the roof strata (Figure 14).

Figure 14 shows that the separation amount of the roof was about $6 \mathrm{~mm}$ within the $4 \sim 8 \mathrm{~m}$ depth range. Within the $2 \sim 4 \mathrm{~m}$ range, the maximum roof separation became $14 \mathrm{~mm}$. The field monitoring data indicated that the new support scheme improved the bearing capacity and stability of the roadway roof, and the deformation failure of the surrounding rocks was well controlled.

\section{Conclusions}

On the basis of the field measurement of the caving accident in the 113101 main transportation roadway of Bojianghaizi Mine, the numerical simulation method was used to investigate the internal roadway deformation and instability mechanism under weakly cemented formation conditions, and a new support scheme was proposed. In the end, a field industrial test was implemented in the subsequent roadway driftage. The following conclusions could be drawn:

(1) The surrounding rock stress deep in the roadway was released after the excavation. Many cracks were generated in the roof strata, and the bearing capacity of the surrounding rocks was reduced. With the continuous upward development of vertical cracks and their penetration through the cracks in the separation bed at the weakly cemented rock strata, a through fractured zone was formed inside the roof, thus triggering the roof caving risk

(2) The crack evolution characteristics inside the roof strata were investigated through the numerical simulation method, and then, the internal deformation and instability mechanism of the rock strata at the weakly cemented roof was analyzed. The results showed that after the weakly cemented roof strata were weakened in water, the roof displacement was enlarged, separation phenomenon appeared in the deep part of the rock strata, and the quantity of cracks was large and presented an evident upward propagation trend, thereby aggravating the caving risk. As a result of the large span, concentration stress could easily form at the vertex angle of the large-section rectangular roadway, and vertical cracks were well developed around the vertex angle; these conditions are not good for roadway maintenance

(3) An improved support scheme was presented on the basis of the instability mechanism analysis for the 
roadway roof. The optimization design of the roadway section and anchor rope support mode was used to improve the integrality and bearing capacity of the roof strata. According to the industrial test results, the maximum separation amount of the roof strata was only $14 \mathrm{~mm}$. Therefore, the control effect on the surrounding rocks was apparent, and this support scheme satisfied the requirements for mine safety production

\section{Data Availability}

The data used to support the findings of this study are available from the corresponding author upon request.

\section{Conflicts of Interest}

The authors declare that there is no conflict of interest regarding the publication of this paper.

\section{Acknowledgments}

This work is supported by the National Natural Science Foundation of China (No. 51674007).

\section{References}

[1] L. YUAN, "Strategic thinking of simultaneous exploitation of coal and gas in deep mining," Journal of China Coal Society, vol. 41, no. 1, pp. 1-6, 2016.

[2] Y. G. He, X. D. Ye, and Z. Wang, "Consideration on the 13th five year plan of coal industry," Coal Economic Research, vol. 35, no. 1, pp. 6-8, 2015.

[3] H. P. Xie, M. G. Qian, S. P. Peng, X. Hu, Y. Cheng, and H. Zhou, "Sustainable capacity of coal mining and its strategic plan," Engineering Sciences, vol. 13, no. 6, pp. 44-50, 2011.

[4] M. E. Chenevert, "Shale alteration by water adsorption," Journal of Petroleum Technology, vol. 22, no. 6, pp. 1141-1148, 1970.

[5] B. Vásárhelyi and P. Ván, "Influence of water content on the strength of rock," Engineering Geology, vol. 84, no. 1-2, pp. 70-74, 2006.

[6] M. Romana and B. Vásárhelyi, "A discussion on the decrease of unconfined compressive strength between saturated and dry rock samples," in Proceedings of the 11th congress of the international society for rock mechanics, vol. 3, pp. 139-142, Lisbon, Portugal, 2007.

[7] G. R. Lashkaripour and E. K. S. Passaris, "Correlations between index parameters and mechanical properties of shales," in Proceedings of the 8th international congress on rock mechanics, pp. 257-261, Tokyo, Japan, 1993.

[8] E. T. Mohamad, F. M. Mohd, A. A. Aziz, O. M. Maiye, and M. Liang, "The effect of moisture content on the strength and anisotropy index of tropically weathered shale," Electronic Journal of Geotechnical Engineering, vol. 18, pp. 5967-5979, 2013.

[9] B. A. Poulsen, B. Shen, D. J. Williams, C. HuddlestoneHolmes, N. Erarslan, and J. Qin, "Strength reduction on saturation of coal and coal measures rocks with implications for coal pillar strength," International Journal of Rock Mechanics and Mining Sciences, vol. 71, pp. 41-52, 2014.
[10] S. Tian, X. Xu, and Z. Li, "Disaster-inducing mechanism in a roadway roof near the driving face and its safety-control criteria," Safety Science, vol. 115, pp. 208-214, 2019.

[11] A. Kumar, D. Kumar, A. K. Singh et al., "Roof sagging limit in an early warning system for safe coal pillar extraction," International Journal of Rock Mechanics and Mining Sciences, vol. 123, p. 104131, 2019.

[12] S. Prusek, S. Rajwa, A. Wrana, and A. Krzemień, “Assessment of roof fall risk in longwall coal mines," International Journal Of Mining Reclamation And Environment, vol. 31, no. 8, pp. 558-574, 2017.

[13] A. Osouli and B. M. Bajestani, "The interplay between moisture sensitive roof rocks and roof falls in an Illinois underground coal mine," Computers and Geotechnics, vol. 80, pp. 152-166, 2016.

[14] E. Ghasemi, M. Ataei, K. Shahriar, F. Sereshki, S. E. Jalali, and A. Ramazanzadeh, "Assessment of roof fall risk during retreat mining in room and pillar coal mines," International Journal of Rock Mechanics and Mining Sciences, vol. 54, pp. 80-89, 2012.

[15] C. A. Bertoncini and M. K. Hinders, "Fuzzy classification of roof fall predictors in microseismic monitoring," Measurement, vol. 43, no. 10, pp. 1690-1701, 2010.

[16] Y. Tai, H. Xia, X. Meng, and T. Kuang, "Failure mechanism of the large-section roadway under mined zones in the ultrathick coal seam and its control technology," Energy Science of Engineering, vol. 8, no. 4, pp. 999-1014, 2020.

[17] H. P. Kang, J. Lin, and M. J. Fan, "Investigation on support pattern of a coal mine roadway within soft rocks - a case study," International Journal of Coal Geology, vol. 140, pp. 31-40, 2015.

[18] F. Gao, D. Stead, and H. Kang, "Numerical simulation of squeezing failure in a coal mine roadway due to mininginduced stresses," Rock Mechanics and Rock Engineering, vol. 48, no. 4, pp. 1635-1645, 2015.

[19] F. Gao, D. Stead, H. Kang, and Y. Wu, "Discrete element modelling of deformation and damage of a roadway driven along an unstable goaf - a case study," International Journal of Coal Geology, vol. 127, pp. 100-110, 2014.

[20] E. Wang, G. Chen, X. Yang, G. Zhang, and W. Guo, "Study on the failure mechanism for coal roadway stability in jointed rock mass due to the excavation unloading effect," Energies, vol. 13, no. 10, p. 2515, 2020.

[21] Q. Bai and S. Tu, "Numerical observations of the failure of a laminated and jointed roof and the effective of different support schemes: a case study," Environmental Earth Sciences, vol. 79, no. 10, p. 202, 2020.

[22] Q. S. Bai, S. H. Tu, C. Zhang, and D. Zhu, "Discrete element modeling of progressive failure in a wide coal roadway from water-rich roofs," International Journal of Coal Geology, vol. 167, pp. 215-229, 2016.

[23] Q. S. Bai and S. H. Tu, "Failure analysis of a large span longwall drift under water-rich roofs and its control techniques," Engineering Failure Analysis, vol. 67, pp. 15-32, 2016.

[24] R. Gao, H. Xia, K. Fang, and C. Zhang, "Dome roof fall geohazards of full-seam chamber with ultra-large section in coal mine," Applied Sciences, vol. 9, no. 18, p. 3891, 2019.

[25] S. Zhang, D. Zhang, H. Wang, and S. Liang, "Discrete element simulation of the control technology of large section roadway along a fault to drivage under strong mining," Journal of Geophysics and Engineering, vol. 15, no. 6, pp. 2642-2657, 2018. 
[26] F. Gao and D. Stead, "Discrete element modelling of cutter roof failure in coal mine roadways," International Journal of Coal Geology, vol. 116, pp. 158-171, 2013.

[27] Q. Tang, W. Xie, X. Wang, Z. Su, and J. Xu, "Numerical study on zonal disintegration of deep rock mass using three- dimensional bonded block model," Advances in Civil Engineering, vol. 2019, Article ID 3589417, 12 pages, 2019.

[28] Itasca Consulting Group Inc, 3D Distinct Element Code (3DEC), Itasca Consulting Group Inc, Minneapolis, MN, USA, 2017.

[29] T. Kazerani and J. Zhao, "Micromechanical parameters in bonded particle method for modelling of brittle material failure," International Journal for Numerical and Analytical Methods in Geomechanics, vol. 34, no. 18, pp. 1877-1895, 2010.

[30] F. Q. Gao and D. Stead, "The application of a modified Voronoi logic to brittle fracture modelling at the laboratory and field scale," International Journal of Rock Mechanics and Mining Sciences, vol. 68, pp. 1-14, 2014. 